\title{
RETHINKING CONCEPTUAL SUFISM: A SYNTHESIS OF ISLAMIC SPIRITUALITY, ASCETICISM, AND MYSTICISM
}

\author{
Meis Al-Kaisi \\ American University of Sharjah, United Arab Emirates \\ E-mail:malkaisi@aus.edu
}

\begin{abstract}
Far from being a school or a sect, Sufism is an ideology, a mode of life, a set of principles, and a 'faith in practice.' Sufism has been addressed and presented by scholars countless times. It has been primarily defined as either Islamic mysticism or as the spiritual dimension of Islam. Yet, as much as mysticism is ineffable as much as the published research is full of tangled definitions that only scholars can comprehend. The traditional approach to the study of Sufism makes the topic burdensome and mentally unattainable to the learned public. This article explains Sufism without using complex terminology or intense presentations of mystical states and stations. It is a scholarly attempt that is ultimately designed to provide a straightforward definition of Sufism. It presents Sufism in a tree-fold manner, as a synthesis of three Islamic principles: Islamic spirituality, asceticism, and mysticism. Each of the three dimensions is explained in an Islamic context to demonstrate the validity of the Sufi trends as being purely Islamic. Spirituality, asceticism, and mysticism are all discussed within the frame of Tradition, that is, the Qur'ān and the Sunna of the Prophet Muhammad.
\end{abstract}

Keywords: Islam; Sufism; spirituality; asceticism; mysticism.

Article history: Received: 11 June 2021 | Revised: 24 October 2021 Accapted: 09 November 2021 | Available online: 01 December 2021

\section{How to cite this article:}

Al-Kaisi, Meis. "Rethinking Conceptual Sufism: A Synthesis of Islamic Spirituality, Asceticism, and Mysticism". Teosofi: Jurnal Tasawnf dan Pemikiran Islam 11, no. 2 (2021): 169-193. https://doi.org/10.15642/teosofi.2021.11.2.169-193 


\section{Introduction}

The purpose of this article is to introduce a new approach to the study of Sufism. It does not aim to present a particular facet of Sufism. This article intentionally avoids specialization. My main objective is to demonstrate a new method by which the reader may gain foundational knowledge about the richly variegated Sufi tradition. There is a need to make Sufism accessible to a wider public by avoiding complex terminology or intense presentations of mystical states and stations when one only seeks to understand the basics. This article provides a simple answer to a basic yet reoccurring question of 'what is Sufism?' Thus far, scholarship has presented numerous answers to the aforementioned question. Nevertheless, Sufism remains a mystery. This article is based on my lecture notes which proved to be a success in conveying what Sufism is and in demonstrating it as an organic Islamic principle, the foundation of which is based entirely on the Qur'ān and the Sunna of the Prophet Muhammad.

Sufism, commonly understood as Islamic mysticism in the West and tasawnuf in the Islamic Arabic world, is perhaps the most controversial current in Islam. Apart from being an aspect of Islam almost impossible to concretely define, it has been a subject of much praise by its proponents perceiving it as the heightened state of spirituality (ihsann) and the core of Islamic faith and practice. Sufism also comes under heavy criticism by its opponents, represented through various religio-political groups in Islam but also through Western scholarship, considering Sufism innovation in religion (bid'a) and, thus, strictly non-Islamic. In the eyes of the advocate, the Sufi is the devotee, the gnostic and the wise man, yet, by the antagonist, he is accused of adopting foreign rituals and practices and fusing those with the fundamental elements of Islam. William Chittick speaks of a "myth that is ... prevalent in religious studies in general and Islamic studies in particular ... that Sufis had little concern for the Sharia (Islamic law), or that they considered it to be a preliminary stage of human development-that is, a stage that one can pass beyond. In other words, it is thought that Sufis were free of the constraints of Islamic 'orthodoxy'."1

1 William C. Chittick, Faith and Practice in Islam: Three Thirteenth Century Sufi Texts (Albany: State University of New York Press, 1992), xii. 
Lloyd Ridgeon challenges early Western scholarship for labelling Sufism as "nothing other than Islamic mysticism." Zeki Saritoprak, on the other hand, explains that Sufism is one of many definitions for the concept of spirituality in Islam. ${ }^{3}$ Although Saritoprak uses the terms spirituality and Sufism interchangeably at times, he declares that from a theological perspective he would still prefer 'spirituality' for it is more inclusive and has a larger connotation.

I attempt to define Sufism in a rather non-conventional way, and that is mainly to provide a more perspicuous explanation. I demonstrate that Sufism is a synthesis of three Islamic principles; that is, Islamic spirituality, Islamic asceticism, and Islamic mysticism.

\section{Previous Scholarship}

Sufism has been defined and described by scholars—-Sufis and non-Sufis, Muslim and Western-in numerous ways and given countless definitions. Despite all the efforts, the idea of Sufism remains abstract. Chittick says that the available definitions of Sufism in the classical Sufi literature "are not logical, historical, or sociological. Instead, they are "allusions" (ishara) designed to alert people to what Sufis achieve or what Sufi practice demands." "4

Western scholarship has tried to define Sufism but "there has never been any consensus concerning the word [Sufism]," Chittick states. ${ }^{5}$ Chittick suggests "that Sufism, in the broadest sense of the term, is Islam's third and innermost dimension. It is primarily concerned with perfecting works and faith, or with sincerity and godwariness." ${ }^{\prime \prime} \mathrm{He}$ admits that "providing a narrower and more specific definition of Sufism is much more difficult." Julian Baldick says:

Sufism is a mystical tradition which, when compared to Christian and European institutions, could be put somewhere between monasticism and Freemasonry. It has many characteristics of monasticism but does not usually preach

\footnotetext{
2 Lloyd Ridgeon, "Mysticism in Medieval Sufism," in L. Ridgeon (ed.), The Cambridge Companion to Sufism (New York: Cambridge University Press, 2015), 125.

${ }^{3}$ Zeki Saritoprak, Islamic Spirituality: Theology and Practice for the Modern World (London: Bloomsbury, 2018).

${ }^{4}$ Chittik, Faith and Practice, 168.

${ }^{5}$ Ibid.

${ }^{6}$ Ibid.

${ }^{7}$ Ibid.
} 
celibacy. It does enjoin mortification of the flesh, and exalts the ideal of poverty, but it includes ordinary members of society in its ranks, with no distinction of clerical versus lay. It emphasizes the love of God and teaches that God and the Sufis have a special relationship that goes back to a primordial Covenant. ${ }^{8}$

As interesting as Baldick's comparison may sound, it does not illustrate what Sufism, as an ideology, mode of life, and as a set of practices actually involves. Annemarie Schimmel declares that each of those who have defined Sufism has "touched upon a different facet, for the phenomenon usually called Sufism is so broad and its appearance so protean that nobody can venture to describe it fully.", Shahida Bilqies explains that each definition "uncovers a different aspect of Sufism, each correct in its proper context, and to grasp Sufism as a whole, one must consider as wide a range of definitions as possible." ${ }^{10}$ Schimmel also says that "to write about Sufism ... is an almost impossible task ... Thus, to set out and delineate some main features of Sufism ... will yield no result that satisfies everybody..." and though "the amount of oriental and occidental literature existent in print and in manuscript is beyond counting, so that even from this viewpoint a full account is not to be achieved." 11

Consequently, a less complex approach is needed. Although one is to appreciate the fact that Sufism is ineffable; that it is better understood experientially rather than theoretically; and that it can only be fully perceived by those who have walked its path. This is, indeed, what makes it mysterious. However, its definition need not be so tangled.

This article presents Sufism in a less conventional way. It intends to simplify the concept of Sufism with an objective to make this ineffably esoteric and, in turn, paradoxical Islamic intellectual tradition better and easier perceived. There is a need to untangle the complex descriptions that seem too complicated to comprehend and thus appreciate. There is a need to make Sufism, as an intellectual

8 Julian Baldick, Mystical Islam: An Introduction to Sufism (London: I.B. Tauris \& Co Ltd, 2012), 3.

9 Annemarie Schimmel, Mystical Dimensions of Islam (Chapel Hill: The University of Carolina Press, 1975), 3.

10 Shahida Bilqies, "Understanding the Concept of Islamic Sufism," Journal of Education \& Social Policy 1, no. 1 (June 2014), 57.

${ }^{11}$ Schimmel, Mystical Dimensions, 3. 
tradition, more accessible. This article also aims to affirm Sufism's Islamic nature and origin.

This article is based entirely on my lecture notes for a 300-level undergraduate course on Sufism. After teaching the course for almost ten years I am convinced that should Sufism be understood and appreciated it cannot be defined merely as Islamic mysticism without a further explanation to what mysticism actually is, nor can it be defined as simply the spiritual dimension of Islam without an explanation to what spiritually actually means. In fact, I argue that Sufism is neither Islamic mysticism or spirituality but it is a combination of these two along with a third principle, that is, asceticism. All three are prefixed with the term 'Islamic' to demonstrate Sufism's pure Islamic nature. The Qur'ān and Hadith are consulted for evidence to support my argument throughout the text.

Accordingly, in this article, Sufism is first divided into three principal components that constitute its quintessence. These are explained individually and, in turn, placed within the context of Islam to demonstrate Sufism as an Islamic tradition right from the outset.

I intentionally avoid any complex terminology or mention of advanced Sufi principles, states, or stations, which are more commonly addressed in the conventional studies on Sufism.

\section{Sufism: A Tri-Faceted Principle}

The simplest way to understand Sufism is to consider it in a three-fold manner, as a synthesis of three key elements. Once we understand each and every one of these, we would then get a step closer to understanding Sufism. Thus, defining Sufism as merely 'Islamic mysticism' is doing it some degree of injustice since a couple of other vital ingredients are hereby missing. A comprehensive definition of Sufism must encompass and address all its qualities.

Sufism is a combination of three Islamic principles. That is, Islamic spirituality, Islamic asceticism and Islamic mysticism. ${ }^{12}$ The term 'Islamic' is prefixed to these elements since in general these are not specific to Islam. Certainly, all three are found in all religions as they are found in Islam. Islam, in its core, has all of these three principles evident in its primary sources, that is the Qur'ann and the

\footnotetext{
12 Meis Al-Kaisi, "The Development of Politico-Religious Movements: A General Overview," in Imed Nsiri (ed.), Arabic Heritage in the Post-Abbasid Period (Cambridge Scholars Publishing, 2019), 128.
} 
Sunna. Therefore, by setting the prefix 'Islamic' the specific qualification is now given. Here we are not speaking of spirituality, asceticism and mysticism generally, but specifically within the context of Islam.

Thus, the first step to understand Sufism is to understand Islam's spiritual, ascetic and mystical dimensions. The next step would be an insight into how the three are connected and how in their association and combination Sufism is established.

\section{Sufism: The Spiritual Dimension of Islam}

At first glans, being the dimension of the metaphysical worldand as such beyond the ordinary range of perception - spirituality and spiritual knowledge could be perceived too surreal and inaccessible to simple mental understanding. Nonetheless, if we observe it as a concept derived from that of the 'spirit' (nafs), matters could get slightly clearer. First, one needs to recognize the spirit as the intangible, non-physical, internal and 'eternal' facet of man in the sense that it has a pre- and post-worldly existence as opposed to the ephemeral perishable body. ${ }^{13}$ Hence, one is to contrast the spirit with that which is visible, tangible, physical and external. Here we have 'body' vs 'spirit', 'material' vs 'spiritual', 'visible' vs 'invisible', and 'ordinary' vs 'extra-ordinary'.

Spirituality has been described in various ways and these varieties in definitions evidence that it is generally a broad term encompassing multiple domains of meanings that may differ among various cultural, national and religious groups. It has been given numerous definitions in the scholarly literature where it has been, at times, separated entirely from religion and, at times, perceived as an intrinsic facet of a religious tradition. In generic terms, spirituality has been defined as "experiential and personal side of our relationship to the transcendent or sacred." "James Nelson states that "the fact that we are spiritual is not a separate nature or characteristic that we have but an inseparable part of all we are and do." ${ }^{15}$ Gavin Picken explains that spirituality is an internal quest for self-development and growth

\footnotetext{
13 Qur'ān 7:172 speaks of a pre-worldly existence of the human spirit. This is a spirit that comprehends and testifies to the Divine presence and His Oneness. There is a primordial covenant between God and the offspring of Adam that Allah is their Lord to which they testify.

${ }^{14}$ James M. Nelson, Psychology, Religion, and Spirituality (New York: Springer, 2009), 8. 15 Ibid.
} 
in sensitivity and in turn a quest for full humanity "resonant with the longings of the human heart for the permanent, eternal, everlasting." 16

This internal quest involves some form of a spiritual exercise that aims at gaining proximity to the Divine by first purifying the spirit from wickedness and then adorning it with beautiful characteristics till it becomes receptive to the Divine presence. Indeed, the spirit must be nurtured for it embodies the good and the evil and may thus be subject to both purification or defilement. Spiritual purification (tazkiyat al-nafs) is thus implicit. The Qur'ān reads:

And by the soul and He who proportioned it (wa-nafsin wa-mā sawwāha), and inspired it [with discernment of] its iniquity and its righteousness (fa-alhamahā fujürahà wa-taqwähā), he has succeeded who purified it (qad aflaha man zakkeäha), and he has failed who instills it [with corruption] (wa-qad khäba man dassāha $\overrightarrow{\text { ) }} .^{17}$

Spiritual purification (tarkiyat al-nafs), as a discipline, is one of Islam's key facets for the attainment of righteousness as documented in both the Qur'ān and the Sunna:

Certainly, did Allah confer [great] favor upon the believers when He sent among them a Messenger from themselves, reciting to them His verses and purifying them and teaching them the Book and wisdom, although they had been before in manifest error. ${ }^{18}$

It is this notion of 'purification,' which is presented as one of several tasks assigned to the Prophet as part of his mission and also as a human requirement for righteousness and success. One is certainly not to deny the fact that there is also the requirement for physical purification in Islam. This ritual is clearly defined by Muslim jurists in fiqh (jurisprudence) literature. Aside from that, tarkiyat al-nafs is a spiritual practice to which the Qur'ān and the Sunna allude.

Muslim scholarship has a two-side approach to this whole principle of spiritual purification. The first of these being the orthodox one which practically involves the application of the commands, prohibitions and etiquettes of Islam. The second being the Sufi approach which treats the inner self, the nafs, and its ability to be inspired, and its potentiality to recognize and to choose between good and evil. Indeed, the Qur'ānic verses mentioned above (91:9-10)

16 Gavin Picken, Spiritual Purification in Islam: The Life and Works of al-Mubasibi (London: Routledge, 2011), 217.

${ }^{17}$ Qur'ān 91:7-10.

18 Qur'ān 3:164. 
are understood to suggest that man has been given a free will to discern between a right action and a sin. In verse 91:9, the Qur'ān affirms that true success (faläh) is only attained by those who purify their nafs.

Accordingly, how is the nafs to be purified? Also, who is the subject of the verb rakka in this specific context? That is, who is it that is causing the purification? Muslim scholarship presents two possibilities, one suggesting God as the subject and the other suggesting the human being. Hence, its either a nafs which God has purified or a nafs which man has purified on a personal level. Seemingly, by considering verses where the nafs is mentioned, it appears that the human nafs is subject to both Divine and human influence. ${ }^{19}$ Qur'ān 79:37-41 affirms that "he who feared the position of his Lord and prevented the nafs from [unlawful] inclination, then indeed, Paradise will be [his] refuge." Qur'ān 3:30 reads:

The Day every soul (nafs) will find what it has done of good present [before it] and what it has done of evil, it will wish that between itself and that [evil] was a great distance. Allah warns you of Himself, and Allah is Kind to [His] servants.

The Qur'ān continues to evidence that the nafs is multifaceted, that it has potentialities as well as a responsibility and accountability. ${ }^{20}$ Thus, when the Sufis address the nafs and seek its development, they are not introducing foreign elements to Islam but applying what is Islamically required.

\section{Three Types of a Nafs}

The Qur'ān speaks of three different types of a nafs in an apparent hierarchal order. There is the one which exhorts to evil (alnafs al-ammāra bi-l-sü), ${ }^{21}$ the reproaching (al-lawwāma), ${ }^{22}$ and the serene (al-mutma'inna $)^{23} \cdot{ }^{24}$ Only to the latter it will be said "O serene soul ( $y \bar{a}-$ ayatubā al-nafs al-mutma”inna), return to your Lord, well-pleased and

19 The listed Qur'ānic verses indicate that it is God who decides who will be purified as well as being the actual source of tazkiya (purification) $2: 174 ; 3: 77 ; 4: 49 ; 24: 21$.

${ }^{20}$ For more examples see Qur'ān 2:123; 2:281; 3:161; 6:164; 14:51; 16:111; 32:13; 39:70; 40:17; 45:22; 74:38.

${ }^{21}$ Qur'ān 12:53.

22 Qur'ān 75:2.

23 Qư'ān 89:27.

24 For a detailed discussion on the three types of the nafs see Gavin Picken, “Tazkiyat al-Nafs: The Qur'anic Paradigm," Journal of Qur'anic Studies 7, no. 2 (2005), 112-117. 
pleasing [to Him], and enter among My [righteous] servants, and enter My Paradise." 25 That is the level to which the aspirant aims to reach on his/her self-developing spiritual journey. Noteworthy, the nafs is also inspired (mulhama) as the Qur'ān reads in 91:8. ${ }^{26}$ This is a facet of the nafs thoroughly addressed in classical Sufi literature. ${ }^{27}$ It is a nafs that is placed after the ammara in the hierarchal order and is one that is "somewhat less evil." 28

\section{The Nafs and its Qualities}

The triliteral root $n-f-s$ occurs in the Qur'ān 298 times in four derived forms. As a noun it is mentioned 295 times with numerous meanings and characteristics. ${ }^{29}$ For instance, the nafs could signify the soul, ${ }^{30}$ the heart, ${ }^{31}$ the human being as a whole, ${ }^{32}$ the human being's power of understanding, ${ }^{33}$ and the inclination to good and evil. ${ }^{34}$ Every nafs will experience death as the Qur'ān repeats "kullu nafsin dhä'iqat al-mawt. ${ }^{\prime 35}$ It is either partially retained during sleep or completely retained at death. ${ }^{36}$ The nafs has desires, appetites and

\footnotetext{
${ }^{25}$ Qur'ān 89:27-30.
}

${ }^{26}$ For a detailed discussion on al-nafs al-mulhama (inspired soul) based on a study of classical Sufi scholars like al-Tirmīdhī, al-Ghazālī, and others, see Laleh Bakhtiar, Qur'anic Psychology of the Self: A Textbook on Islamic Moral Psychology (Chicago: Kazi Publications, 2009).

${ }^{27}$ See al-Tirmidhî̀s treatise on the heart entitled Bayann al-farq bayn al-sadr wa-l-qalb wal-fu'äd wa'l-lubb in Nicholas Heer et al., Three Early Sufi Texts (Louisville, Fons Vitae, 2003). See also Muhammad al-Ghazālī, Alchemy of Happiness, trans. Claud Field, ed. L. Cranmer-Byng and S. A. Kapadia (New Delhi, India: Global Vision Publishing House, 2020).

${ }^{28}$ Heer et al., Three Early Sufi, 7.

${ }^{29}$ Muḥammad Fuād 'Abd al-Bāqī, al-Mu'jam al-Mufahras li Alfāza al-Qur'ān (Cairo: Dār wa-Mațābi' al-Sha‘b, 1958-9), 710-714.

${ }^{30}$ Qur'ān 6:93.

31 In Qur'ān 7:205 and 12:77 two qualities of the heart are being attributed to the nafs. These being remembrance (dhikr) and concealing a secret (sirr). This indicates a link between the nafs and the heart. Classical Sufi literature has addressed the interrelationship between the heart and the nafs considering the Qur'ānic reference of the former being a facet of the inspired nafs. See Tirmidhì's Bayan al-farq in Heer's Three Early Sufi Texts; and al-Ghazāli’s Alchemy of Happiness. See also Bakhtiar, Qur'ànic Psychology.

32 Qur'ān 31:28.

${ }^{33}$ Qur'ān 27:14.

${ }^{34}$ Qur'ān 50:16; 75:2; 79:37-41.

35 Qur'ān 3:185; 21:35; 29:57.

36 Qur'ān 39:42. 
needs. It prefers ease over hardship, it is more commonly impatient rather than patient. It has the virtue of generosity but also the quality of miserliness. The nafs is envious and jealous. It may experience fear, anxiety and distress. There are also the qualities of pride and arrogance evident in the nafs as well as regret and grief. The nafs may comprehend an idea, be affected by eloquent speech, and conceal feelings. As a consequence of all of these qualities and intellectual faculties, and as a result of its ability to distinguish between good and evil, the nafs is responsible for its actions. ${ }^{37}$ Spirituality, as a discipline, aims to purify the nafs from all its negative potentialities and enrich it with the positive counterparts. Since the hierarchy is evident, spirituality in this case becomes inescapable.

\section{Spirituality and the Heart}

Spirituality also addresses the heart $(q a l b)$ for it too can be subject to both purity and defilement. As has been mentioned above, the Qur'àn sometimes uses the term nafs to signify the heart and would also, in turn, use the term qalb to signify 'consciousness' and the 'inspired nafs' (al-nafs al-mulhama). ${ }^{38}$ Therefore, the heart is used independently to signify a number of spiritual states, qualities and actions. The Qur'ān and the Hadith have addressed the human heart as the seat of faith and, indeed, as the organ of emotional realization and spiritual perception. ${ }^{39}$ Qur'ān 22:46 reads, "For indeed it is not the eyes that grow blind, but it is the hearts, which are within the bosoms, that grow blind." Qur'ān 2:225 reads, "But He will take you to task for that which your hearts have earned."

The Prophet said: "there is a piece of flesh in the body; if it is purified the whole body becomes pure but if it gets spoilt the whole body becomes spoilt; indeed, it is the heart." ${ }^{\prime 0}$ This indicates that

\footnotetext{
${ }^{37}$ For a detailed discussion see Picken, "Tazkiyat al-Nafs", 107-12.

38 Bakhtiar, Qur'anic Psychology.

${ }^{39}$ For instance, in Qur'ān 50:37 the heart indicates the intellect. Qur'ān 22:46 reads "So have they not travelled through the earth and have hearts by which to reason (fa-takün labum quiūb yáqilüna bihä)." In Qur'ān 13:28 the heart can be assured by the reembrace of God (alā bi-dbiker Allāh tatma'innu l-qulüb). This confirms that remembrance (dhikr) is an action of the heart. It also indicates that tranquility and peace are achieved through dhiker, a form of meditation highly commended by the Sufis. As was already mentioned, tranquility is also a state of the nafs. A fundamental link between the heart and the nafs is hereby evident.

40 Muhammad al-Bukhārī, al-Jami‘ al-Saḥ̣̣̄̄ (Riyadh: Dār al-Salām, 1999), 52; Muslim al-Qushayrī, Șahīḥ Muslim (Riyadh: Dār al-Salām, 2000), no. 1599.
} 
human righteousness begins from within. The Prophet also said, "verily God does not look at your appearance and your wealth but $\mathrm{He}$ looks at your hearts and at your deeds." ${ }^{41}$

Just as there are three types of a nafs evident in the Qur'ān, there are four types of hearts listed by the Prophet:

The naked heart in which there is a light similar to a lantern which illuminates; the heart which is locked in an envelope; the inverted heart; and the divided heart. The naked heart is that of the believer, and the lantern therein is its light [from God]; the locked heart is that of the non-believer; the inverted heart is that of the hypocrite who knows but refuses [the truth]; the divided heart is that in which there is part faith and part hypocrisy. The part of faith therein is comparable to a good plantation irrigated by pure water; and the part of hypocrisy therein is comparable to a wound washed by both pus and blood. The stronger of these two tendencies will dominate the heart. ${ }^{42}$

It is the 'divided' heart of faith and hypocrisy, the one torn between righteousness and wickedness, it is that which spirituality aims to purify from any defilement and to enlighten with the light of the Divine. Sensibility of the heart to its tendencies, both positive and negative, is thus key to spiritual enlightenment, and so is sensibility to the diverse influences to which the heart is subjected, both internal and external-the internal being the self (al-nafs) and the external being both Satan (al-shaytän or Ibliss) and the world (al-dunya). The Prophet confirmed, "verily, the heart of the son of Adam gets overturned more easily than water boiling in a pot," 43 and "the heart has been so called because of its turnings [taqallubibi]: it is similar to a feather hanging from a tree which the wind blows around back and forth." ${ }^{44}$

In Sufism the heart is key. Tarif Khalidi writes, "it is the heart (qalb) rather than the mind ('aq) that is the visual spiritual organ in Sufi devotions, and it is the heart that is the seat of spirituality." 45 Classical Sufi literature has addressed the heart and defined it as the

\footnotetext{
${ }^{41}$ Muslim, Șahīh, nos. 2564, 4651.

42 Tayeb Chourief, Spiritual Teachings of the Prophet: Hadith with Commentaries by Saints and Sages of Islam, trans. Edin Q. Lohja, ed. Jane Casewit (Louisville, KY: Fons Vitae, 2011), 59.

43 Ibid., 64.

44 Ibid.

45 Tarif Khalidi, Images of Mubammad: Narratives of the Prophet in Islam Across the Centuries (United States, Doubleday Religion, 2009), 159.
} 
seat of understanding and consciousness. ${ }^{46}$ Al-Ḥārith al-Muhāasibī, for instance, "regards the heart as the essence of the self, an immaterial principle which has the predominant control of our conscious life, by which reality is perceived and interpreted." 47 Though it is the source of positive human qualities, the heart can also be deviated and fall ill. Its illness would lead to ignorance and unbelief. Sufis speak of the heart which embraces God. It is the heart of the faithful, clean from the filth of this worldly life and from the darkness of the nafs that is ammara bi-l-sü. This state of purity of the heart (safä' al-qalb) is achieved by means of following the Sharia. It becomes in turn a prerequisite for achieving the heightened state of spirituality, the state of ihsan (virtue). Thus, the qalb can be defiled and blinded by the nafs which exhorts to evil though not affected by it. ${ }^{48}$

Sufis say that the heart must be emptied of all that is not God. This is the ultimate goal. Qur'ān 26: 87-89 reads, "And do not disgrace me on the Day they are [all] resurrected. The Day when there will not benefit [anyone] wealth or children. But only one who comes to Allah with a sound heart (bi-qalbin salim)." Similarly to the nafs, the heart seemingly has potentialities. It may be sound or corrupt and accordingly can be conditioned. Sufis thus perceive the heart like a rusty mirror that requires constant polishing.

\section{The Prophet and Spirituality}

When addressing the spiritual facet of the Prophet's personality one ought to look at theory as well as practice. What has been said and what has been practically applied. There is a number of Prophetic reports that serve the evidence. For instance, "being rich is not [due to] having a lot of material wealth but being [truly] rich is [having] richness of the soul (ghina ' al-nafs)." ${ }^{49}$ Wealth measurement is normally a material task. However, the Prophet is pointing out that this criteria for evaluating human beings is false. The real measure of wealth is

\footnotetext{
46 See Tirmidhì's Bayān al-Farq in Heer's Three Early Sufi Texts; and al-Ghazālìss Alchemy of Happiness.

${ }^{47}$ Bakhtiar, Qur'ānic Psychology.

48 In a Sufi work on the different stations (maqämät) of the heart, Tirmidhī gives a detailed description. These stations have characteristics and functions and they are all associated with the spiritual stages of the Sufi path. There are four stations to the heart arranged in concentric spheres, and four spiritual stages on the path. See Tirmidhì's Bayān al-farq in Heer's Three Early Sufi Texts, 16-24, 26.

${ }^{49}$ Bukhārī, al-Jami‘ al-Sạ̣ị, no. 6446.
} 
spiritual. Yet, how is the nafs to be rich? What are the qualities that evidence its wealth? One of them is rida (contentment). The Prophet said, "The one who is contented with God as his Lord, Islam as his religion and Muhammad as his prophet has truly 'tasted the flavour of faith." 50 This might sound simple although contentment in not an easy quality to obtain as it is associated with Divine predestination, the good of it and the bad. It is contentment with the manifestation of the Divine Will. Patience (sabr) is another quality that enriches the nafs. The two are, in fact, related. True patience is tested when disaster first strikes. To have patience with the Divine Will is only possible if one is content with it. As for the 'taste,' it is used as a metaphor for 'experience.' This gives rise not only to the concept of rida but also to the concept of dhawq (taste) which is a critical idea in Sufism, that is, the idea of experiential knowledge.

Apart from statements and theoretical evidence, the Prophet is said to have sought proximity to the Divine through the application of certain practices. As mentioned earlier, spirituality is an exercise by which one is to purify the nafs from base characteristics to, in turn, adorn it with fine qualities for the ultimate goal of growth in sensitivity till the nafs becomes mutma'inna (serene). We must first turn back to the Qur'anic verses that assign to the Prophet the duty of tarkiya. ${ }^{51}$ Though the Qur'ann alludes to the idea that God alone is the source of tazkiya, and at times to man's free will and the ability to purify himself by discerning between good and evil, there are four verses in which the subject of the verb is a chosen emissary, that is the Prophet Muhammad. ${ }^{52}$ The Qur'ān also explains the process as to how the Prophet is to purify man. One of the means is defined in Qur'ān 9:103 where it says "Take a charity (sadaqa) from their wealth (min amwälibim) to cleanse them (tutabirubum) and purify them (turakkihim)." Indeed, charity in the form of zakat is one of the five pillars of Islam, that is, a compulsory act clearly defined by Sharia law. There is also the supererogatory charity (sadaqa), which is defined by the Prophet in various ways, not necessarily monetary, like a good or just word, a good act, or even a smile.

\footnotetext{
${ }^{50}$ Muslim, al-Musnad al-Sabìh, no. 151.

${ }^{51}$ Qur'ān 2:151. Muslim scholarship has explained the tazkiya here as to purify the Arabs from polytheism and wickedness. See 'Abd al-Haqq Ibn 'Ațiya, al-Muharrar alWajū fì Tafsìr al-Kitāb al-W ajì (Cairo: al-Majlis al-A 'lā li-l-Shu'ūn al-Islāmiyya, 1982). ${ }^{52}$ Qur'ān 2:129; 2:151; 3:164; 62:2.
} 
Sufis speak of riyadat al-nafs (disciplining of the self) and mujahbadat al-nafs which is a spiritual form of jihad. The Prophet is said to have referred to the spiritual form of jihad against one's own nafs as the greater one (al-akbar) as opposed to the physical jihad at the battle-fields as the minor one (al-asghar). ${ }^{53}$ In Sufism jihad denotes the battle between man and the base desires of his nafs. Once man knows the nature of his nafs and its negative tendencies and its own particular defects and faults then man is to try to strive and struggle against it. Muhāāibī was particularly concerned with mujāhadat al-nafs along with muhäsabat al-nafs (self-examination/accounting of the self), a practice that won him the title of Muhāsibib. ${ }^{54}$

One of the objectives of spirituality is to gain proximity to the Divine. A hadith qudsi (sacred) explains the way:

... My servant draws nearer to me (yataqarrabu) by means of nothing more dearer to me than that which I have made compulsory upon him. My servant continues to draw closer to me through supererogatory acts until I love him; and when I love him I become his ear with which he hears, his eye with which he sees, his hand with which he grasps and his foot with which he walks. If he were to ask [something] of Me, I would give it to him and if he were to seek My help, I would grant him it. $^{55}$

Hence, those who seek proximity to the Divine shall not do so in any manner other than by abiding by God's commandments. The hadith indicates that by acting in accordance with what God has commanded and by performing the supererogatory the seeker becomes a beloved to God (mahbuib). Once a beloved to God then this person is guided. He sees through God. He hears through God. He acts and walks having God as his guide on the path. This person is also Divinely protected. In another hadith:

God Almighty states, 'I fulfil my servant's expectation of me and I am with him when he remembers Me. If he remembers Me to himself then I remember him to Myself; if he remembers me in a gathering then I remember him in gathering better than it. If he were draw near to me a hands span then I would draw nearer

\footnotetext{
53 On 'greater jihad' see John Renard, "al-Jihād al-Akbar: Notes on a Theme in Islamic Spirituality", The Muslim World 78, no. 3-4 (April 2007), 225-242. DOI: 10.1111/j.1478-1913.1988.tb02825.x

${ }^{54}$ For more on Muhạsibī see Picken, Spiritual Purification.

${ }^{55}$ Bukhārī, al-Jāmi’ al-Saḥih, no. 6502.
} 
to him an arm's span; and if he draws near to me a hand's span I would draw nearer to him a fathom and if he came to me walking, I would come to him running. ${ }^{56}$

It thus becomes obvious why Sufis stress on the notion of remembrance (dhikr) which is one of their key daily practices. Qur'ān 33:41 says, "O believers, remember Allah abundantly." The Prophet said:

Do not indulge in excessive talk except when remembering Allah. Excessive talking without the remembrance of Allah hardens the heart; and those who are the farthest from Allah are those whose hearts are hard. ${ }^{57}$

One could ask the question whether the Prophet applied what he preached or did he declare himself to be above the ordinary law which he imposed on others. In fact, there is ample evidence of the Prophet's embodiment of the Qur'ānic message. In his Futubät, Ibn 'Arabī gives a beautiful description saying “'The Qur'ān is the speech of God and His epithet (sifa) while Muhammad is the epithet of God Almighty in his totality." 58

\section{Sufism: The Ascetic Dimension of Islam}

Asceticism is renunciation of worldly pleasures and worldly comforts. The objective is attainment of holiness, righteousness and piety. Worldly pleasures and comforts could be any ephemeral matter that the human nafs not necessarily needs but certainly desires. This could be material wealth for instance. This could also be matters that are physically necessary yet their consumption exceeds necessity. This could be food and sleep for instance. All the excess becomes a luxury, a pleasure and a comfort. Asceticism aims to (1) minimize consumption to the level of necessity, and (2) deny the nafs the luxury of excess which brings about worldly pleasure and comfort. This act of self-denial is a prerequisite for self-discipline (riyadat al-nafs) which helps tame and control the nafs that is prone to evil. This process of abstinence, self-denial, and in turn self-discipline helps man in his struggle against his nafs and its carnal desires (mujähadat al-nafs). Thus, asceticism serves the tool for self-discipline and in turn for spirituality.

\footnotetext{
${ }^{56}$ Bukhārī, Al-Jāmi al-Saḥih, no. 7405.

57 Sunnah.com. Al-Nawawī, Riyāẹ al-săliḥin, no. 1518. https://sunnah.com/riyadussalihin/17/8

${ }^{58}$ Ibn al-'Arabī, al-Futubät, 7/68-69 as cited in Khalidi, Images of Mubammad, 173.
} 
Islam has its ascetic dimension, the evidence to which is in the Qur'ān and in the Sunna. The Arabic term for asceticism is zubd. The first comprehensive and accurate definition of the term zubd that was offered by modern Western scholarship was the one put forward by Louis Massignon in The First Encyclopaedia of Islam where he defined zuhd as "abstinence; at first from sin, from what is superfluous, from all that estranges from God ...; then abstinence from all perishable things by detachment of the heart ..., complete asceticism, renunciation of all that is created." 59

In a recent study on zubd, Christopher Melchert uses the term 'renunciation' instead of 'asceticism' when defining zubd and refers to the practitioner of zubd (in Arabic zähid, pl. zubhäd) as 'renunciant' rather than 'ascetic. ${ }^{60}$ Melchert argues that 'the Greek word askètés means literally 'athlete' and thus corresponds most closely not to zäbid in Arabic but to mujtabid' that is 'someone who maintains a strenuous schedule of devotions, especially supererogatory ritual prayer. ${ }^{91}$ Nonetheless, almost two decades earlier, Genevieve Gobillot had addressed this terminological issue when she defined zubd as a term that "embraces numerous nuances, divided between two principal meanings: on the one hand, 'renunciation' in the sense of detachment, of indifference to things of this inferior world; on the other, 'asceticism' in the sense of privation, mortification, tests imposed on the carnal soul (nafs).",62

In the sphere of classical Islamic literature, zubd has been defined in many ways, which have shown that it is a wide concept that includes various aspects and components, such as wara' (scrupulous abstention from the use of everything doubtful in law), tawakkul (trust in God), rida (contentment with God), and taqwà (fear of God). Abū Sulaymān al-Dārānī (d. 214/830), for instance, defined wara' as the basis of zubd. ${ }^{33}$ Sahl al-Tustarī (d. 283/895) said that wara' is merely

\footnotetext{
${ }^{59}$ Louis Massignon, "Zuhd", The Encyclopaedia of Islam, $1^{\text {st }}$ ed. (1913-36), consulted online on 13 October 2021 http://dx.doi.org/10.1163/2214-871X_ei1_SIM_6112. For an earlier definition see Leah Kinberg, "What is Meant by Zuhd", Studia Islamica 61 (1985), 27.

${ }^{60}$ Christopher Melchert, Before Sufism: Early Islamic Renunciant Piety (Berlin/Boston: De Gruyter, 2020), 11.

${ }^{61}$ Ibid.

${ }^{62}$ Genevieve Gobillot, "Zuhd", The Encyclopaedia of Islam, 2 ${ }^{\text {nd }}$ ed., consulted online on 13 October 2021 http://dx.doi.org/10.1163/1573-3912 islam SIM 8201

${ }^{63}$ Kinberg, 'What is Meant by Zuhd', 41.
} 
one aspect of zuhd. ${ }^{64}$ As for ridā, Fudayl b. 'Tyād (d. 187/803) said that "the origin for renouncing this world is contentment with God." ${ }^{65}$ Shaqī al-Balkhī (d. 194/810) believed that "a human being cannot cope with zubd, unless he trusts God." ${ }^{66}$ Yet, rida and tawakkul are not contradictory definitions as Kinberg explains, but rather complementary components of one concept: " $Z u$ ubd is that you trust God more than you trust yourself,' this is tawakkul ... 'and that you be happier with misfortune rather than being recompensed for it,' this is rida." $" 67$

The essence of zubd has been expressed by Kinberg as "the purification of the soul and total devotion to God." "68 Al-Zuhri (d. 124/741) once said that al-zubd fi al-dunya " is neither being disheveled nor living in squalor and neglecting your body. It is denying your soul all forms of desires." ${ }^{69}$ Moreover, al-Shiblī (d. 334/945) said: "zubd is to renounce anything which is not God" and Dhū al-Nūn al-Miṣrī (d. 246/861) remarked that al-zubd fi al-dunya is achieved only when one renounces his soul. ${ }^{70}$ That is evidently congruent with the concept of tarkiyat al-nafs and, thus, with spirituality. Thus, zubd becomes a method by which man may achieve spirituality.

It is important to note that there are three types of zubd: spiritual, physical, and one that is a combination of both. One of the most common definitions of zubd that illustrates the precedence of spirituality over the physical form of zubd is that of Sufyān al-Thawrī (d. 162/778), who said that "al-zubd fi al-dunya is the hope for short duration [qisar al-amal] rather than eating tough food and wearing an ' $a b \bar{a}$ ' (a tough woollen cloak). ${ }^{, 71}$ This clearly demonstrates the intrinsic relationship between spirituality and zuhd. A man who leads an ascetic mode of life does so for a thought that dominates his existence, a thought that focuses on death and the world to come rather than on what is offered on that distracting plate of life. Having said that, spiritual renunciation of carnal appetites and pleasures that one's self

\footnotetext{
${ }^{64}$ Ibid.

${ }^{65}$ Ibid., 31.

${ }^{66}$ Ibid., 33.

${ }^{67}$ Ibid.

${ }^{68}$ Ibid., 34.

${ }^{69}$ Ibid., 30.

${ }^{70}$ Ibid.

${ }^{71}$ Ibid., 34.
} 
and heart desire leads certainly to a form of physical abstinence as well.

The Qur'ann and the Sunna make it clear that man should not ignore his existence in the world, but is allowed to enjoy what God has permitted of food, drink, clothing and the like. "But seek, with that which Allah has bestowed on you, the home of the Hereafter, and forget not your portion of lawful enjoyment in this world." ${ }^{72}$ Hence, we find many statements that speak of zubd moderately and demonstrate it as a path to a reasonable life. Al-Junayd (d. 297/910), for instance, declared that zubd is "thinking little of the world and wiping out its effects from the heart." 73 Another statement expressed that "rubd is not abandoning the whole world; it is merely being indifferent to it and taking only a [sufficiency] of it." 74 Zubd has also been described as "merely following the badith and the sunnah," 75 which indicates that it is an organic product of Islam and a recommended practice for every pious Muslim.

The notion of renouncing this world's temporary ease and comfort for the sake of eternal felicity in the Hereafter has been inspired by the Prophet as well as echoed numerous times in the Qur'ān. Qur'ān 2:183 declares, 'O you who have believed, decreed (kutiba) upon you is fasting as it was decreed upon those before you that you may become righteous (la'allakum tattaqün)." Indeed, fasting is the most physical form of self-denial as food is certainly one of the greatest worldly comforts and pleasures made permissible (halä) for man to consume. Yet, God calls upon every Muslim to deny that pleasure for a required time to attain righteousness (taqwa). ${ }^{76}$ Two facts to be highlighted here: (1) the Qur'ān not only promotes zubd but declares it a compulsory act, and (2) zuhd leads to righteousness and proximity to the Divine which meets the objective of zubd mentioned at the beginning of this section.

In addition to fasting there are other acts of zubd mentioned in the Qur'ān, though perhaps less obvious. For instance, almsgiving

\footnotetext{
${ }^{72}$ Qur'ān 28:77.

${ }^{73}$ Kinberg, "What is Meant by Zuhd", 36.

74 Ibid.

${ }^{75}$ Ibid., 40.

${ }^{76}$ Taqwa is a state of consciousness, righteousness, sensitivity and proximity to the Divine. The notion of taqwa is linked in the Qur'ān to nobility in character: "Indeed, the most noble of you (akramakum) in the sight of Allah is the most righteous of you (atqäkum)." See Qur’ān 49:13.
} 
(zakät), pilgrimage (bajj), and even prayer. Noteworthy, the application of zakät, as mentioned earlier, is also a method by which one is to be spiritually purified. All of the mentioned ascetic (or 'renunciant' as Melchert would prefer to call it) practices are, in fact, amongst the five compulsory pillars of Islam.

Moreover, the Qur'ann declares the insignificance and the transience of this world, "Short is the enjoyment in this world. The Hereafter is (far) better for him who fears Allah."" "The life of the world is only an amusement and play! Verily, the home of the Hereafter - that is the life indeed, if they but knew." ${ }^{, 78}$

There is no doubt that zubd as a concept and as a practice, like spirituality and spiritual purification, is part of the Sunna. According to tradition, the Prophet is said to have described "the man who reaches the highest level of zubd" as "the one who did not forget the graves and the decay, and preferred the eternal upon the perishable, and considered himself among the dead." "T9 The Prophet also said, "detachment from the world appeases the heart and the body whereas worldly desire generates worry and distress, and idleness hardens the heart." 80

It is evident that the main components of zubd are states of the human heart rather than a demonstration of ascetic/renunciant behaviour or mere contentment with simple food and clothes. Also, zubd denotes a general way of conduct in accordance with the Sunna. ${ }^{81}$

\section{Sufism: The Mystical Dimension of Islam}

Further to my attempt to describe what Sufism is, the term mysticism equally requires a definition. Webster's Third New International Dictionary alone gives three definitions. At first it describes it as "the experience of mystical union or direct communion with ultimate reality." Secondly, as "the doctrine or belief that direct knowledge of God, of spiritual truth, or ultimate reality ... is attainable through immediate intuition, insight, or illumination and in a way differing from ordinary sense perception or ratiocination," and,

\footnotetext{
77 Qur'ān 4:77.

${ }_{78}^{78}$ Qur'ān 29:64.

${ }^{79}$ Kinberg, "What is Meant by Zuhd", 38.

${ }^{80}$ Chourief, Spiritual Teachings of the Prophet, 61.

81 For reports that present the Prophet's humble mode of life see for example Bukhārī, al-Jāmi al-Sahịh 70, hadith 2, 9, 13, 14, 25.
} 
thirdly, as "vague speculation, belief without foundation." Baldick, however, prefers to avoid a dictionary-style definition and concentrates instead on isolating specific elements of mysticism. One of these elements is secrecy, and another is "the sense of a higher, privileged knowledge ... connected to the idea of intimate communion or experience, which, perhaps by its very nature (as opposed to a requirement for secrecy) cannot be disclosed." 82

On the other hand, Schimmel explains that mysticism "contains something mysterious, not to be reached by ordinary means or by intellectual effort ... Mysticism has been called the great current which goes through all religions ... Mysticism can be defined as love of the Absolute." $\$ 83$

Sufism is also defined as "reliance on spiritual intuition or exalted feeling as the means of acquiring knowledge of mysteries inaccessible to intellectual apprehension." ${ }^{84}$ Additionally, it is defined as "belief in the possibility of union with the divine nature by means of ecstatic contemplation." ${ }^{85}$ Nevertheless, perhaps the most comprehensive definition is with Robert Ellwood who explained it as an "experience in a religious context that is immediately or subsequently interpreted by the experiencer as encounter with ultimate divine reality in a direct nonrational way that engenders a deep sense of unity and of living during the experience on a level of being other than the ordinary." 86

When comparing mysticism with zubd, the latter is perceived as being inspired by fear of judgment and the choice to refrain from sin in fear of God, mysticism, by contrast, is inspired by the love of God. As Schimmel says,

the power that separates true mysticism from mere asceticism is love. Divine love makes the seeker capable of bearing, even of enjoying, all the pains and afflictions that God showers upon him in order to test him and to purify his soul. ${ }^{87}$

Having said that, it should be noted that this is the popular view of mystical Islam, which is not expressed by some of its advocates from the classical period, such as Abū Nu'aym al-Iṣfahānī. In his

\footnotetext{
${ }^{82}$ Baldick, Mystical Islam, 2.

${ }^{83}$ Schimmel, Mystical Dimensions, $3 \mathrm{f}$.

84 Picken, Spiritual Purification, 217.

85 Ibid.

${ }^{86}$ Robert S. Ellwood, Mysticism and Religion (Prentice-Hall, 1980), 29.

${ }^{87}$ Schimmel, Mystical Dimensions, 4.
} 
Hilyat al-Awliyà 'wa Tabaqät al-Asfiyä', 'love' comes as a consequence of many different states rather than at the center of Sufism, and Sufism, in turn, is placed at the center of Islam rather than at the fringes of it. In Abu Nu'aym's Hilya, the two most crucial Sufi figures among the popular view, that is Rābī'a al-'Adawiyya (d. 184/801) and Manșūr al-Hallāj (d. 309/922), for whom 'love of God' was perhaps the key aspect of their mysticism, are simply not included. ${ }^{88}$ Nonetheless, it is generally understood that mystics, as opposed to ascetics, "tried to achieve a sensitive relation with God." 89

\section{Mysticism in the Qur'ān and the Sunna}

The absolute first verse in the opening chapter of the Qur'ān reads, "All praise is for Allah, Lord of all worlds." Right from the outset, man is informed that there is more to what one perceives with one's physical senses. The worldly life is certainly perceived, experienced and understood by man. Science, as a matter of fact, explains it. What about those other worlds that the Qur'àn speaks of? These are, indeed, beyond man's physical or even rational perception. These are metaphysical realms of existence that neither human reason nor science can comprehend. Here we have the world of the angels, the jinn, the soul (al-rüb), the Hereafter, the barrier between life and death known as the barzah, and the Divine realm. All of these are mentioned in the Qur'an yet none is within human rational perception. They are like parallel spheres to the worldly sensory life that are concealed from human vision. Therefore, they require a nonsensory organ of perception to be experienced. Something like a sixth-sense, one that is particularly used to perceive the extraordinary, that is, the spiritual as opposed to the five senses that perceive the physical.

Prophet Muhammad has had access to the non-sensory worlds. He saw angels, received revelation, rode mysterious animals, met prophets from the past, ascended heavens, seen Paradise and Hellfire,

88 Meis Al-Kaisi, "Sufi Apologia in the Guise of Biography: The Case of Abu

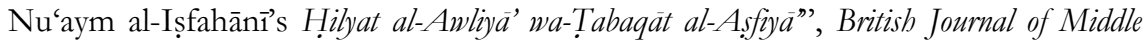
Eastern Studies 43, no. 1 (2016), 115-134. https://doi.org/10.1080/13530194. 2015.1075378.

${ }^{89}$ Louis Massington et al., "Tașawwuf”, The Encyclopaedia of Islam , 2nd ed., consulted online on 13 October 2021 http://dx.doi.org/10.1163/1573-3912 islam COM 1188. 
and possibly even met God. All of this was experienced on an extraordinary night, the isrä' and mi'räj, and recorded in the Qur'ān..$^{90}$ The Prophet experienced Gabriel in his angelic form as well as seen him in his human form. ${ }^{11}$ Nonetheless, the ultimate mystical event of all is that of revelation. If man were to rationalize revelation he would not reach to a place other than possibly madness. For no reason can explain the ineffable, that Divine communication delivered through an angel to man.

Mystical knowledge is gained through mystical experiences which require techniques of contemplation (tadabbur/tafakekur) and meditation (muräqaba), as well as a variety of spiritual disciplines and ascetic practices. This knowledge is experiential. It is known as ma'rifa (gnosis). Tlm, on the other hand, is theoretical knowledge picked up in literature. Noteworthy, in order to achieve a mystical experience one is to combine the techniques of contemplation and meditation with spirituality and zubd. In other words, for anyone to have a mystical experience, that person is to include the three elements that constitute Sufism. For Sufism is inclusive of spirituality, zubd and mysticism in simultaneous motion.

Let us consider the event of revelation in CE 610 at the Mount of Nour and the Cave of Hira where Gabriel came to meet the Prophet for the first time. Historical sources confirm that the Prophet then was in a state of seclusion and fasting, both of which are ascetic practices. He was also meditating and contemplating over Mecca and the religious situation of its people. Historical sources confirm that the Prophet was never a polytheist but a monotheist from the outset. He would spend many days/nights in seclusion in Hira, always in a state of fasting, meditation and contemplation. It was on one of those occasions that God send his messenger Gabriel with the absolute first revelation. This confirms that meditation and contemplation techniques in combination with ascetic practices and spirituality are a prerequisite to gain extra-ordinary knowledge delivered through a mystical experience.

Having established the fact that the notion of mysticism is evident in the Qur'ān and in the prophetic personality, it is only rational to ask whether meditation and contemplation are Islamic

\footnotetext{
${ }^{90}$ For the Isrä' and Mi'raj see Qur'ān 17:1.

${ }^{91}$ Sunnah.com. Sahih Muslim, online, no. 8 e. https://sunnah.com/muslim/1
} 
principles? The answer to this is, indeed, they are. The terms tadabbur and tafakkur (contemplation, reflection) appear numerous times in the Qur'ānic text referring to people contemplating in mosques or reflecting on the creation of heavens and earth. Qur'ān 4:82 reads, "Do they not reflect (yatadabbarūna) on the Qur'ān?" which appears again in 47:24 with noteworthy continuation saying "or are there locks upon their hears? (am 'alà qulüb aqfälubä)." Here is an obvious Qur'ānic reference to the human heart as a spiritual, non-sensory organ of perception through which man may reflect and contemplate and, in turn, receive and perceive knowledge. Hence, it is evident that Islam (1) speaks of a mystical dimension, and (2) encourages practices of meditation and contemplation.

\section{Concluding Remarks}

Sufism is commonly defined as the mystical dimension of Islam. Although it is generally a fair-though ultimately basicdescription, Sufism is, in fact, a synthesis of three principles. These are, Islamic spirituality, zubd and mysticism. The concept of Sufism is part of the Qur'ānic message and its fundamental principles are no other than following the Sunna and the Sharia. Sufism found its inspiration in the Qur'annic verses that speak of (1) the creation of the spirit and its potentialities, (2) the necessity for self-discipline and selfpurification, (3) the requirement to adopt zubd to attain righteousness, (4) the existence of realities beyond human physical perception, and (5) divine love and of God's enduring presence in the hearts of the faithful.

It would not be an exaggeration to consider Sufism the spirit of Islam and the Sufi a Muslim in the truest sense. A Sufi is one who observes the religious duties required but also adheres to perform the supererogatory to gain proximity to the Divine. Sufis have realized that existence in this world is ephemeral and thus strived for the real and eternal life in the Hereafter. They bid farewell the pleasures in this world and thought of nothing and no one but God. They elutriated their heart from worldly desires, restrained their tongues to the mention of God only, and compelled their deeds to follow His commands.

Fundamentally, Sufis aim to achieve an intimate and loving relationship with God, one that brings about a sense of unification with the Divine. They are cognizant of the threat of Judgment Day 
and the tortures of Hell, but they also realize the love of God, "that He loves them and they love Him." 92 Sufis have evidently interpreted this verse as applying to them specifically. They have looked upon themselves as being this special group of people - the better, mightier and more righteous in this religion, that is, the elite of the Muslim community.

\section{Bibliography}

'Ațiya, 'Abd al-Haqq Ibn. al-Muharrar al-Wajiz fì Tafsìr al-Kitäb al-Wajīi. Cairo: al-Majlis al-A‘lā li-l-Shu'ūn al-Islāmiyya, 1982.

Al-Kaisi, Meis. "Sufi Apologia in the Guise of Biography: The Case of Abū Nu'aym al-Iṣfahānī's Hịlyat al-Awliyà' wa-Tabaqāt al-Asfizyā", British Journal of Middle Eastern Studies 43, no. 1, 2016. https://doi.org/10.1080/13530194.2015.1075378.

Al-Kaisi, Meis. "The Development of Politico-Religious Movements: A General Overview," in Imed Nsiri (ed.), Arabic Heritage in the Post-Abbasid Period. Cambridge Scholars Publishing, 2019.

Bakhtiar, Laleh. Qur'anic Psychology of the Self: A Textbook on Islamic Moral Psychology. Chicago: Kazi Publications, 2009.

Baldick, Julian. Mystical Islam: An Introduction to Sufism. London: I.B. Tauris \& Co Ltd, 2012.

Bāqī (al), Muhammad Fuād 'Abd. al-Mưjam al-Mufahras li Alfāă alQur'ān. Cairo: Dār wa-Mațābi' al-Sha‘b, 1958-9.

Bilqies, Shahida. "Understanding the Concept of Islamic Sufism," Journal of Education \& Social Policy 1, no. 1, June 2014.

Bukhārī (al), Muhammad. al-Jami al-Sahīḥ. Riyadh: Dār al-Salām, 1999. Chittick, William C. Faith and Practice in Islam: Three Thirteenth Century Sufi Texts. Albany: State University of New York Press, 1992.

Chourief, Tayeb. Spiritual Teachings of the Prophet: Hadith with Commentaries by Saints and Sages of Islam, trans. Edin Q. Lohja, ed. Jane Casewit. Louisville, KY: Fons Vitae, 2011.

Ellwood, Robert S. Mysticism and Religion. Prentice-Hall, 1980.

Ghazālī (al), Muhammad. Alchemy of Happiness, trans. Claud Field, ed.

L. Cranmer-Byng and S. A. Kapadia. New Delhi, India: Global Vision Publishing House, 2020.

Gobillot, Genevieve. "Zuhd", The Encyclopaedia of Islam, $2^{\text {nd }}$ ed., consulted online on 13 October 2021 http://dx.doi.org/10.1163/1573-3912_islam_SIM_8201

${ }^{92}$ Qur'ān 5:54 
Heer, Nicholas et al., Three Early Sufi Texts. Louisville, Fons Vitae, 2003.

Khalidi, Tarif. Images of Muhammad: Narratives of the Prophet in Islam Across the Centuries. United States, Doubleday Religion, 2009.

Kinberg, Leah. "What is Meant by Zuhd", Studia Islamica 61, 1985.

Massignon, Louis. "Zuhd", The Encyclopaedia of Islam, $1^{\text {st }}$ ed. (1913-36), consulted online on 13 October 2021 http://dx.doi.org/10.1163/2214-871X_ei1_SIM_6112.

Massington, Louis et al., "Tașawwuf", The Encyclopaedia of Islam , $2^{\text {nd }}$ ed., consulted online on 13 October 2021 http://dx.doi.org/10.1163/1573-3912_islam_COM_1188

Melchert, Christopher. Before Sufism: Early Islamic Renunciant Piety. Berlin/Boston: De Gruyter, 2020.

Nelson, James M. Psychology, Religion, and Spirituality. New York: Springer, 2009.

Picken, Gavin. "Tazkiyat al-Nafs: The Qur'anic Paradigm," Journal of Qur'anic Studies 7, no. 2, 2005.

Picken, Gavin. Spiritual Purification in Islam: The Life and Works of alMubasibi. London: Routledge, 2011.

Qushayrī (al), Muslim. S.ậị̣ Muslim. Riyadh: Dār al-Salām, 2000.

Renard, John. "al-Jihād al-Akbar: Notes on a Theme in Islamic Spirituality", The Muslim World 78, no. 3-4, April 2007. DOI: 10.1111/j.1478-1913.1988.tb02825.x

Ridgeon, Lloyd. "Mysticism in Medieval Sufism," in L. Ridgeon (ed.), The Cambridge Companion to Sufism. New York: Cambridge University Press, 2015.

Saritoprak, Zeki. Islamic Spirituality: Theology and Practice for the Modern World. London: Bloomsbury, 2018.

Schimmel, Annemarie. Mystical Dimensions of Islam. Chapel Hill: The University of Carolina Press, 1975.

Sunnah.com. Al-Nawawī, Riyāed al-sälibìn, no. 1518. https://sunnah.com/riyadussalihin/17/8

Sunnah.com. Sabih Muslim, online, no. 8 e. https://sunnah.com/ muslim/1 